\title{
O ESPAÇO SAGRADO E O NASCIMENTO DA POLIS EM MÉGARA HYBLAEA
}

Ana Carolina Porto Nunes Munhoz

Dissertação apresentada ao Programa de PósGraduação em Arqueologia, do Museu de Arqueologia e Etnologia da Universidade de São Paulo, para obtenção do título de Mestre em Arqueologia.

Orientador: Prof ${ }^{\mathrm{a}}$. Dr ${ }^{\mathrm{a}}$. Elaine Farias Veloso Hirata 
UNIVERSIDADE DE SÃO PAULO

MUSEU DE ARQUEOLOGIA E ETNOLOGIA

PROGRAMA DE PÓS-GRADUAÇÃO EM ARQUEOLOGIA

\section{O ESPAÇO SAGRADO E O NASCIMENTO DA POLIS EM MÉGARA HYBLAEA}

Ana Carolina Porto Nunes Munhoz

São Paulo

2006 


\section{DEDICATÓRIA}

Dedico este trabalho ao meu avô Luiz (em memória), à minha avó Terezinha e principalmente ao meu namorado William. 


\section{AGRADECIMENTOS}

Agradeço, em primeiro lugar, à admirável professora Elaine Farias Veloso Hirata, que orientou essa pesquisa. Agradeço por sua dedicação, apoio, compreensão e por todos os ensinamentos que me foram passados nestes quatro maravilhosos anos de convivência.

Agradeço a todos os professores do Museu de Arqueologia e Etnologia, especialmente à professora Maria Beatriz Borba Florenzano.

Agradeço a todos os funcionários do Museu de Arqueologia e Etnologia da Universidade de São Paulo.

Agradeço os funcionários e ex-funcionários da biblioteca do MAE pela grande contribuição às nossas pesquisas. Um agradecimento especial a Eleuza e Vera. Muito obrigada pelo carinho e apoio.

Agradeço a CNPq, instituição responsável pelo apoio financeiro à pesquisa.

Agradeço a todos meus atuais colegas de trabalho, especialmente aos funcionários e professores da EMEF Amélio de Paula Coelho.

Agradeço a meus ex-professores e eternos mestres e amigos da UNESP de Franca Moacir Gigante e Maria Celeste Fachin, cujo apoio e ensinamentos passados foram fundamentais desde o início de minha trajetória como estudante universitária e assim o serão pra sempre. Muito obrigada por tudo.

Agradeço aos meus queridos amigos e colegas de pesquisa. Um agradecimento especial a minha amiga Lílian e a meu amigo Danilo. Agradeço também a Vanessa e Cibele, pela enorme ajuda na elaboração do abstract.

Agradeço a toda família Guimarães Munhoz, especialmente a meu pai Rafael e a minha avó Maria Cecília, grandes entusiastas de meus estudos.

Agradeço a toda família Nunes, especialmente a minha mãe, Maria Tereza, que sempre compreendeu a importância dos meus estudos e a minha querida avó Terezinha, que sempre me apoiou.

Agradeço, enfim, ao meu grande e eterno amor William, que me fez acreditar em mim mesma e me incentivou como ninguém a lutar pelos meus objetivos. Muito brigada pelo carinho, pelo amor incondicional e por transformar minha vida em algo muito melhor. Muito obrigada por existir. 